\title{
Trends in fine art, as exemplified by the legacy of W. Kotarbiński, and architecture of the late $19^{\text {th }}$ and early $20^{\text {th }}$ centuries
}

\section{Tendencje w sztukach wizualnych (na przykładzie twórczości W. Kotarbińskiego) i architekturze końca XIX - początku XX wieków}

\begin{abstract}
This article analyses the commonality of trends in fine art and architecture of the late $19^{\text {th }}$ and early $20^{\text {th }}$ centuries. By the examples of the legacy of Wilhelm Kotarbiński, Arnold Böcklin, Oleksandr Verbytsky and Valerian Rykov it is proven how antique subjects were creatively reconsidered in the age of historicism-eclecticism and modern art. The difference between the paintings and bas-reliefs of the late $19^{\text {th }}$ and early $20^{\text {th }}$ centuries from the Greek images is analysed and the main features of the legacy of famous artists are determined. The distribution of a specific kind of national romanticism in Russia - the neo-Russian style of Abramtsevo and Talashkino - is characterised.
\end{abstract}

Keywords: trends, fine art and architecture, historicism-eclecticism, modern

\section{Streszczenie}

W dziedzinie architektury przeanalizowano tendencje w sztuce i architekturze końca XIX i początku XX wieków. Na przykładzie twórczości Wilhelma Kotarbińskiego, Arnolda Böcklina, Aleksandra Wierbickiego i Waleriana Rykowa udowodniono, że w dobie historyzmu-eklektyzmu i secesji ulegały twórczemu przemyśleniu wątki antyczne. Zbadano różnice między malowidłami i płaskorzeźbami z końca XIX i początku XX wieku a greckimi obrazami. Określono indywidualne cechy twórczości znanych malarzy. Scharakteryzowano specyficzną odmianę narodowego romantyzmu w Rosji - neorosyjski styl Abramcewa i Tałaszkina.

Słowa kluczowe: tendencje, sztuka i architektura, historyzm-eklektyzm, secesja 


\section{INTRODUCTION}

The period of the second half of the $19^{\text {th }}$ century was marked by a change in the ruling elite; the bourgeoisie gradually came to power as a result of a series of bourgeois revolutions replacing the reign of the aristocracy. Since the customer always influenced the style preferences and favours, the sphere of activity of the ruling elite prompted the implementation of scientific and technological discoveries. The invention of the locomotive prompted the emergence of large-scale structures for stations and depots. The invention of cement, Portland cement and concrete caused a real revolution in the technology of construction. Buildings of a fundamentally new functional purpose appeared - passages, department stores, exchanges, offices, etc. This led to radical changes in the style of architecture.

The period of the second half of the $19^{\text {th }}$ century is the period of the emergence of $19^{\text {th }}$-century rationalism, the so-called 'style of engineers', from which the 'style of artists' the modern (Secession, Art Nouveau, Jugendstil) - organically grew up in the 1890s. In parallel with the innovative rationalism of the nineteenth century, there was historicism-romanticism, which was based on the citation of the styles of past epochs. Historicism-romanticism also corresponded to the tastes of the new ruling elite; therefore, mansions were erected with the active use of historically themed paintings in the interiors.

\section{ESSENTIAL PART}

There is typically much in common between the fine art and the architecture of a particular era. Such parallels can be made between fine art and architecture of Ancient Egypt, Greece, Rome, Gothic, Baroque, Classicism, and similar eras. This is why the analysis of the work of the Polish artist Wilhelm Kotarbiński objectively reflects not only artistic trends at the turn of the century, but also characterises the artistic tastes of society and proves the commonality of architectural and artistic trends.

Wilhelm Kotarbiński was born into a noble family in 1848, in the town of Nieborów in the province of Warsaw. From 1867 to 1871, he attended painting classes at the Warsaw Society of Fine Arts, and in 1871, he went to Rome and he remained there for ten years. After returning from Italy, Kotarbiński was invited by Adrian Prakhov to work in Kyiv on interior paintings of St. Volodymyr's Cathedral built in the Russian-Byzantine style. Prakhov himself was a professor at University of St. Volodymyr, an archaeologist and art historian. He directed paintings and was not seriously concerned with the paintings of Kotarbiński, but highly appreciated his graphic works.

In some scientific sources, Kotarbiński is described as an artist of a new style of modernism due to his passion for mystical and supernatural subjects, and themes of death, but it is also true that Kotarbiński was at the same time a representative of academicism at 
the end of the $19^{\text {th }}$ century, with a combination of modernism and symbolism. In his legacy, there are paintings on mythological, historical and religious themes.

Another facet of the artist's work is the interior paintings of St. Volodymyr's Cathedral and the Kyiv mansions of the philanthropists Tereshchenko and Khanenko (III. 1). Thus, the interior of the mansion of Bohdan and Varvara Khanenko was decorated with thirteen panels. Of particular note are the side panels of the plafond ('Cupid with a bow', 'Cupid in flowers', 'Cupid among flowering branches and blue birds', 'Garland of flowers', 'Cupid is flying', 'Vase with flowers', 'Butterfly on the flowering branch', 'Flowering branch and butterflies', 'White butterfly on the flowering branch'), picturesque panels over the northern and southern doors or so-called desportes ('Allegory of sleep', 'Allegory of death') and the composition of the frieze with the images of the four civilisations of the ancient world - Egypt, India, Greece and Rome. These images of civilisations are in the Red Room (III. 1).

It is necessary to analyse the plots of these images in more detail as they indicate the synthesis of different trends in the architecture of this period. The image of Cupid is not typical of modernism; these traditions in historicism originate from the classicism of the late $18^{\text {th }}$ and early $19^{\text {th }}$ centuries, whereas the images of flowers and especially butterflies in modernism came from borrowed Japanese art traditions based on admiring the nature. The origins of paintings on the themes of ancient civilisations should be considered in the context of archaeological excavations performed in the $19^{\text {th }}$ century followed by the appearance of a number of works on historical themes. Instead, the appearance of the allegory of sleep and death is a direct trend in the fine art and architecture of the modern world, which declares the transition from sleep to the eternal sleep and in which the theme of death is romanticised.

Wilhelm Kotarbiński was engaged in the painting of the plafond of another mansion belonging to Mykola Tereshchenko. Architectural 'mirrors' were decorated with decorative panels featuring Old-Russian scenes of epics. In particular, there are the subjects 'Dobrynia Nykytych, his wife and Aliosha Popovych', 'The Bogatyrs', 'Dobrynia Nykytych's fight with Illia Muromets', 'Solovii Budymyrovych with Prince Volodymyr in Kyiv', and 'Dobrynia Nykytych saves Prince Volodymyr's niece along with other princesses from the Serpent's Cave'. Four paintings were painted on canvas with oil paints and fixed to the ceiling on wooden stretchers. Kotarbiński painted the ceiling of the lobby of Tereshchenko's mansion, probably during the years 1887-1900, which was either at the same time or at the end of the work on the paintings of St. Volodymyr's Cathedral. Plots selected by the artist themselves were also on Old-Russian themes: 'The Second Battle of Dobrynia Nykytych with the Dragon Gorynych', 'Dobrynia Nykytych in Departure', 'Dobrynia Nykytych and Dunai Ivanovych', and 'Solovii Budymyrovych'.

Comparison of the subjects of paintings of two mansions indicates the existence of two artistic trends in the society. These both use historical subjects, but in the compositional and figurative interpretation of the era of historicism-romanticism and use scenes based 
on artistic and imaginative doctrine of Art Nouveau. Another source of creativity which influenced many artists and also W. Kotarbiński is national romanticism, namely the so-called 'neo-Russian style', established in the nineteenth century by the artists Abramtsevo and Talashkino. It was Russian national romanticism that became a certain opposition to mystical and pessimistic plots of European modernism as it was not based on the theme of life and death, afterlife and visions but on folklore tales and epics. This branch of national romanticism became extremely popular in Russia, as it was associated with national identity and national Slavic uniqueness. Mass replication of this phenomenon is evidenced by similar scenes on millions of postcards that were bought. Artists emerge who mostly draw postcards and thus become popular (in particular Serhii Solomko).

By the example of Kyiv houses, one can trace the common trends of using ancient Greek plots in a new way of interpreting and combining antique stories and stylistics of modernism. As examples, we selected the house at 15 Luteranska Street (1908, architect Oleksandr Verbitskyi) and the house at 4 Museum Lane (1909, architect Valerian Rykov).

The house at No. 15 was erected in Mariia Krasovska's estate as a revenue house. Its feature is the construction of a complex relief and decoration of the main facade in the style of 'flat decorative modern', while there is much less signs of decorative modern in it (windows and doorways, decor, artistic metal) than, say, in the Kyiv objects of another modern architect - Ignacy Ledochowski, a Pole by birth (Kachkovsky Clinic at 33 Honchar Street, revenue houses at 19 and 21 Vietrova Street and 32 Velyka Zhytomyrska Street). The signs of modern in the house at 15 Luteranska Street include the use of majolica, moulded phytomorphic inserts under the sub-eaves belt, the asymmetry of the facade with the displacement of the main axis to the left, along the faceted bow window of the second to fourth floors and the decorative majolica panels on the curvilinear gable (III. 1). It is this majolica panel that is a vivid example of the combination of the ancient plot and modern traditions which is also present in the image of playing Satyr of W. Kotarbiński (III. 3).

This panel represents the famous painting by a Swiss artist, Arnold Böcklin, a distant descendant of the German artist Hans Holbein, who in his work is quite close to W. Kotarbiński. This picture is named 'Spring Evening' (III. 4) and illustrates the ancient Greek legend 'Pan and Syrinx'. This plot was used by artists of the age of classicism, but in the era of modernism, it was redefined in accordance with new artistic trends and preferences. In the modern era, Greek subjects lack pathos, academicism, images become dynamic, at the same time (in case of the legacy of Böcklin) certain anxiety and even ominousness occur in them. Just like Wilhelm Kotarbiński, Arnold Böcklin reproduced non-real plots in paintings, but instead, a world of mystical images and legends. Unlike most of the paintings by Böcklin, where some mysticism, tension or ominousness is felt in the ancient stories, the painting 'Spring Evening' does not have that expression and reflects the scene of Pan's play on the syrinx reed, which two forest nymphs are dreamingly listening to. This painting was very well known, not only 
in Europe but also in the territory of the Russian Empire; therefore, its choice as a plot for a majolica panel (performed by the artist A. Kozlov in the Abramtsevo ceramic workshop) was not accidental.

The combination of the ancient Greek plot, already in the interpretation of the late modern art, is present on the facade of the house at 4 Museum Lane. This seven-storey revenue house belonged to engineer Isaak Isserlis and at that time was considered to be one of the most comfortable in Kyiv. The peculiarity of the facade solution of the house is a combination of features of rationalist and classicised modern.

The most interesting features are the stucco decorations of the facade executed on the sketches of the famous sculptor Theodore Balavensky, especially the multi-figure composition 'Triumph of Phryne' in the inter-window spaces on the second floor. In turn, this bas-relief was created on the basis of the picture 'Phryne at Poseidon feast in Eleusis' by Henryk Siemiradzki, which is stored in the Russian Museum in St. Petersburg. The painting depicts the moment of Phryne's reverence as the goddess of Aphrodite, the bas-relief on the façade has the same scene, even Phryne's position is the same here.

\section{GENERAL CONCLUSIONS}

An overview of the general trends in fine art and architecture at the end of the $19^{\text {th }}$ and early $20^{\text {th }}$ centuries suggests that they arose under the influence of common factors. In particular, for the architecture of the period of historicism-eclecticism, the use of the motives of the styles of past epochs was inherent. Such directions emerged as Neo-Gothic, pseudo-Mauritanian and Russian-Byzantine styles and neoclassical; in some buildings, motifs of Indian or Egyptian architecture were used. It is noted that the fascination with the styles of the past in architecture was predetermined, firstly, with the discovery of Egyptian civilisation by Europeans in the days of Napoleon, and secondly, with the excavations of Pompeii which were held in the nineteenth century. In turn, the novels by Boleslaw Prus and Walter Scott contributed to the interest of the general public in the ancient civilisations and the East. This led to the rapid spread of pseudo styles of the $19^{\text {th }}$ century and neo styles of the $20^{\text {th }}$ century in the territory of Western Europe and the Russian Empire.

The modern style was of particular importance in fine art and architecture in the late $19^{\text {th }}$ and early $20^{\text {th }}$ centuries; this radically transformed the very construction of painting and graphic work and the object of architecture. This is due to the specific origins of the modern, which was based, inclusively, on Eastern art, especially Japanese, for which understatement, allegory, symbolism, asymmetry in the construction of the composition, mystical and fantastic subjects, a specific colour range, and the theme of death are just characteristic. These plots penetrate first into Western European art, and through the work of Pre-Raphaelites, 
they influence the origins of modernism in the mansions of the architect Victor Horta, transforming according to the conditions of construction. The legacy of the painter Wilhelm Kotarbiński is a typical example of the synthesis of modernism and symbolism, where there are also themes of death, mystical debris, and creatures from the afterworld. This is why the notion that the nervousness of the lines and silhouettes of modernism in architecture and the ominous moulded decor of buildings was a premonition of the crisis in society, World War I, can be fully attributed to the legacy of Wilhelm Kotarbiński, as often, an artist intuitively foresees the future in his paintings. 


\section{7}

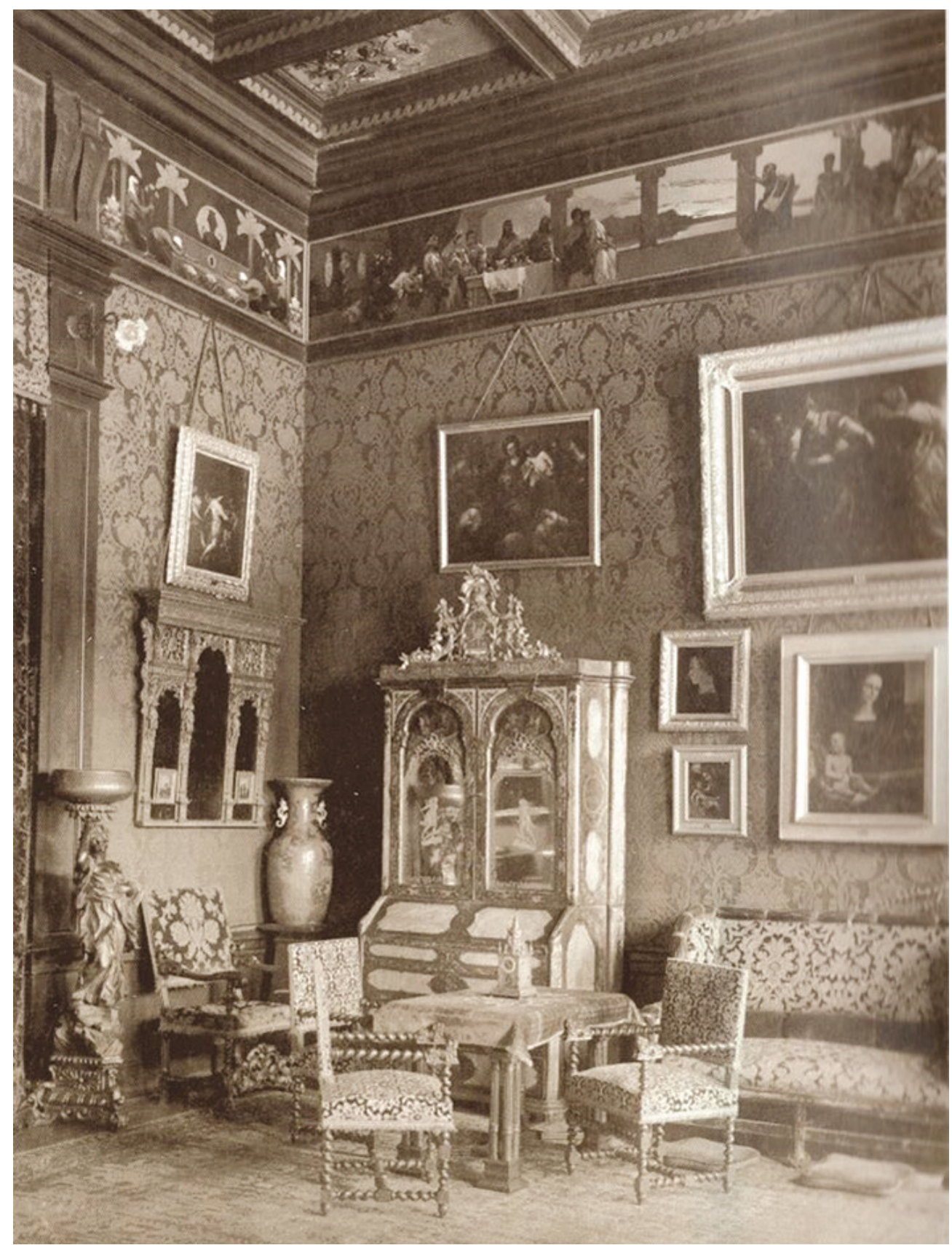

III. 1. Kotarbiński's paintings in the 'Red Room' of the Khanenko mansion (source: https://vakin.livejournal.com/1496402.html) 


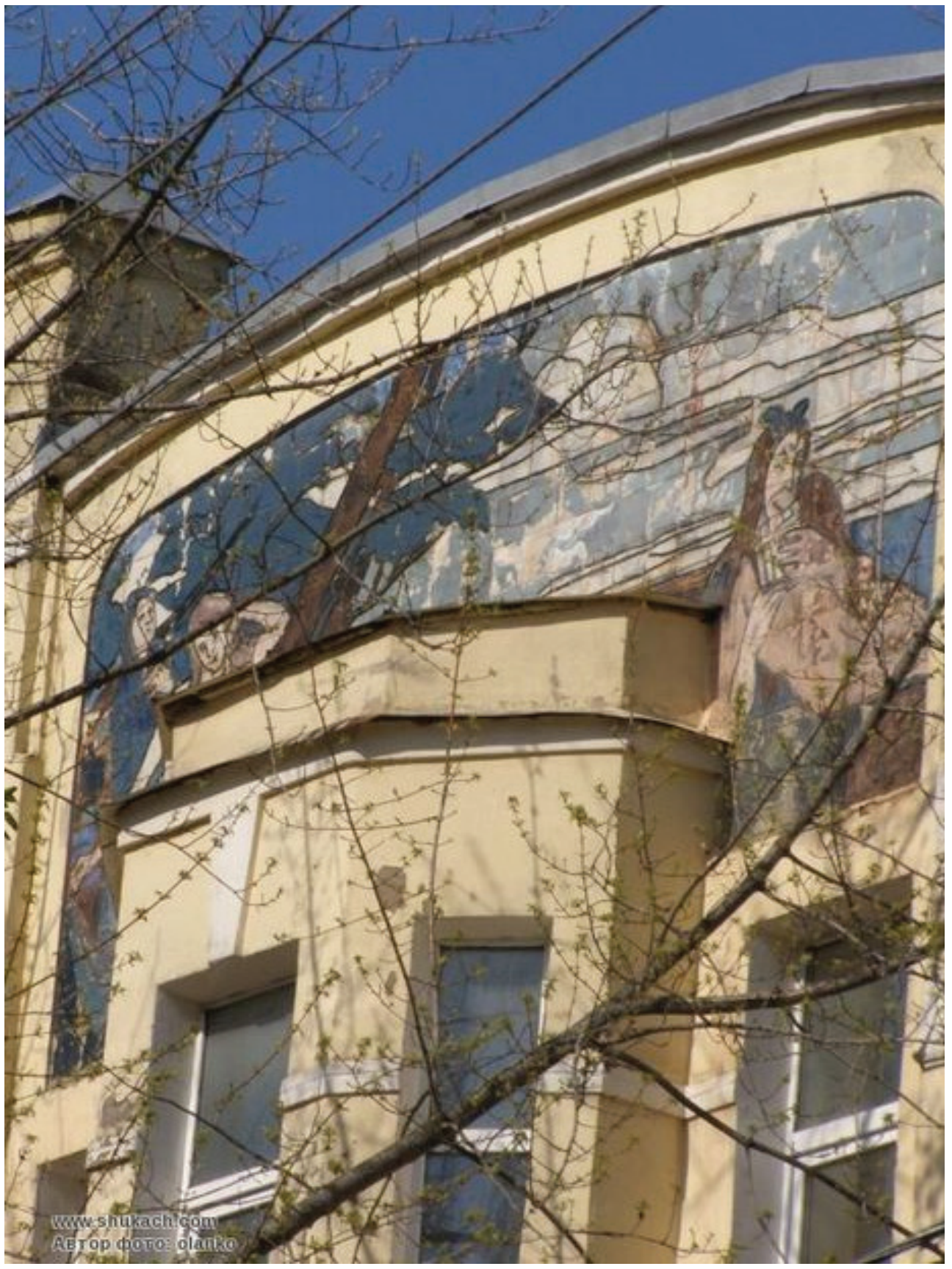

III. 2. Majolica panel on the façade of the house at 15, Luteranska Street (source: https://www.pinterest.com/pin/268527196517781432) 


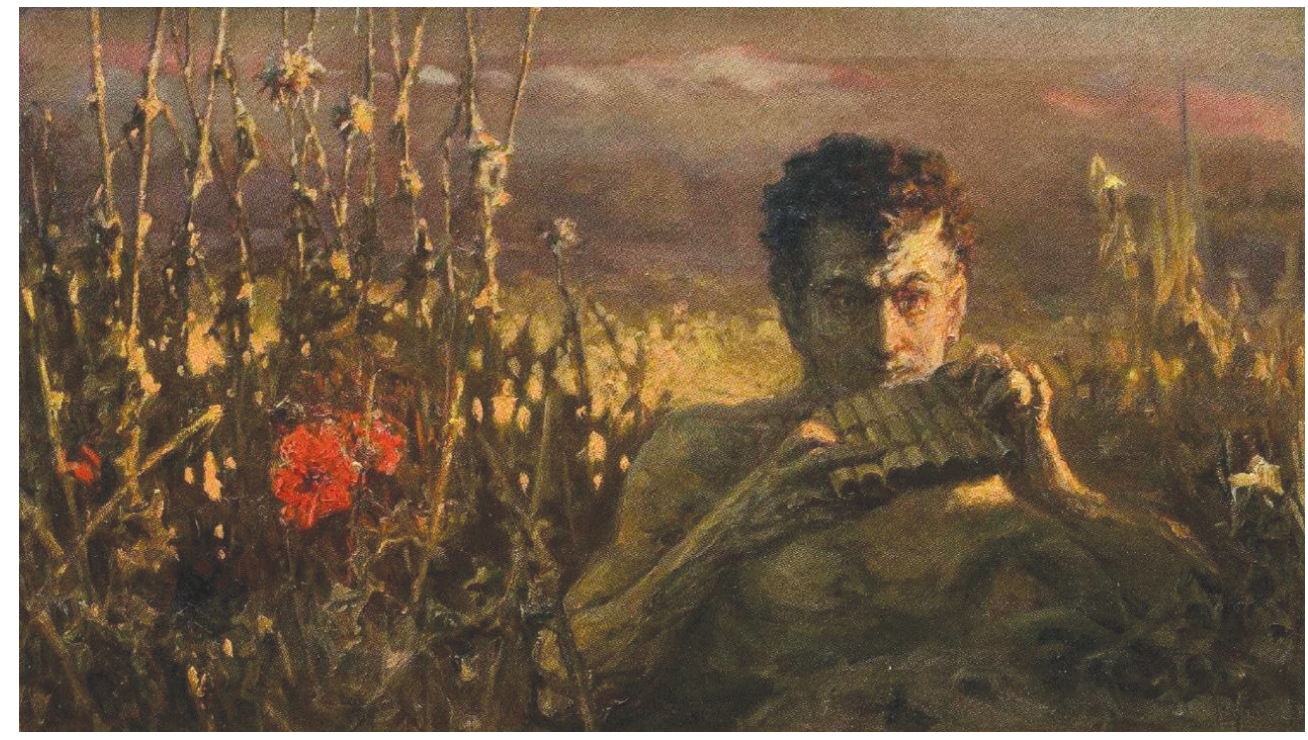

III. 3. W. Kotarbiński, Satyr, $19^{\text {th }}$ century, oil, canvas (source: https://artsandculture.google.com/asset/spring-evening)

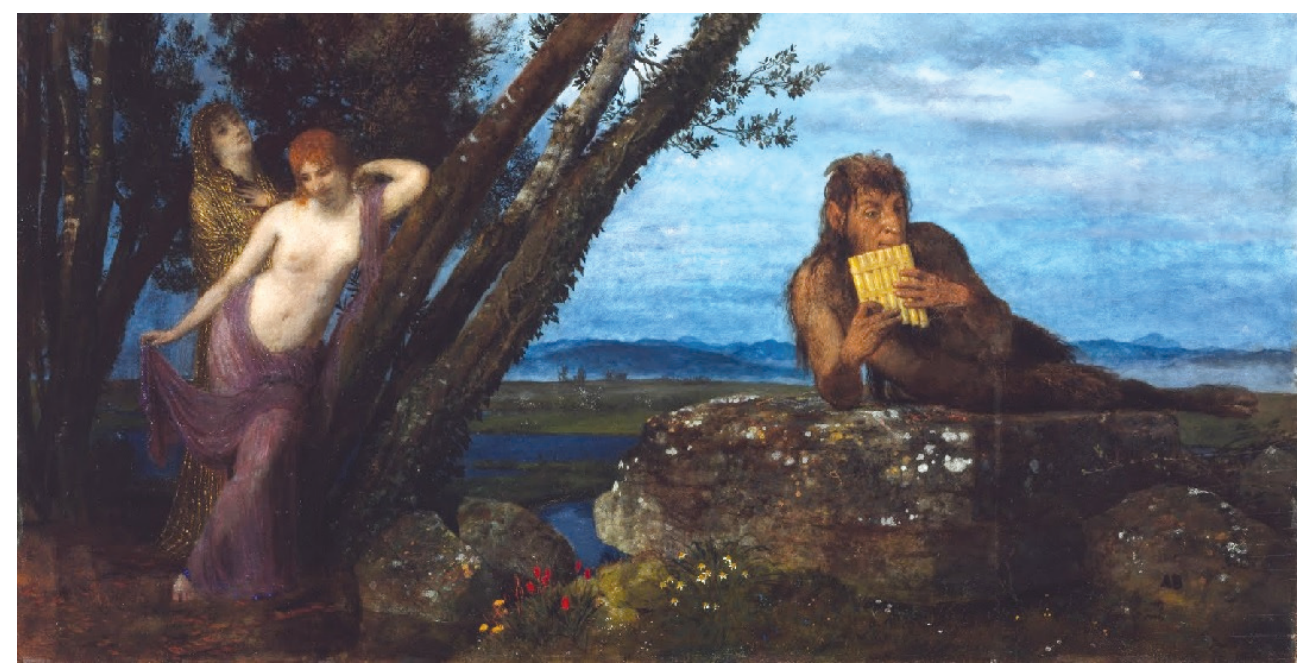

III. 4. A. Böcklin, Spring Evening, 1879, oil, wood (source: https://artsandculture.google.com/asset/spring-evening) 


\section{REFERENCES}

Drug O., Malakov D., Mansions of Kyiv, Kyiv: Kyi 2004.

Ivashko Yu., Houses of Kyiv with Gothic Elements: research on history and architecture, Kyiv: Hopak 2004.

Ivashko Yu.V., Houses of Kyiv in Modern Style: research on history and architecture, Kyiv: Hopak 2006.

The house at 23, Luteranska Street. State Archive of the city of Kyiv, fund 100 - series 1 , no. 206, 1314; fund 163 - series 6, no. 145; series 46, no. 157.

The house at 4, Museum Lane. State Archive of the city of Kyiv, fund 100 - series 1, no. 1080. 